\title{
Pecan Tree Productivity, Fruit Quality, and Nutrient Element Status using Clover and Poultry Litter as Alternative Nitrogen Fertilizer Sources
}

\author{
M. Lenny Wells ${ }^{1}$ \\ Department of Horticulture, University of Georgia, Tifton Campus, 4604 \\ Research Way, Tifton, GA 31793
}

Additional index words. Carya illinoinensis, orchard, legumes, alternate bearing, micronutrients, tree nuts

\begin{abstract}
The recent increase in the cost of synthetic fertilizer dramatically reduces the profit margin for pecan [Carya illinoinensis (Wangenh.) K. Koch] producers. The objective of this study was to investigate the effects of clover and poultry litter on the orchard soil, horticultural, and nut quality parameters of pecan in the southeastern United States. The following treatments were evaluated; 1) crimson clover (Trifolium incarnatum L.); 2) poultry litter; 3) crimson clover + poultry litter; 4) ammonium nitrate $\left(\mathrm{NH}_{4} \mathrm{NO}_{3}\right)$; and 5 ) untreated control. Application of poultry litter with or without clover often led to higher soil phosphorous (P) and potassium (K). Poultry litter application with and without clover led to higher leaf $P$ in the final year of study. The recurring low pecan leaf $K$ in the presence of clover without additional $K$ application suggests that $K$ nutrition may be especially important in orchards where clover is used. Clover and/or clover + litter occasionally led to enhanced pecan leaf concentrations of iron (Fe), copper $(\mathrm{Cu})$, and zinc $(\mathrm{Zn})$. Over the course of the study, yields were more consistent from year to year in the clover, litter, and clover + litter treatments, as indicated by the low alternate bearing intensity $(I)$ from 2008 to 2011. Leaf elemental tissue analysis, pecan yield, and quality indicate that poultry litter and clover provide adequate nitrogen $(\mathrm{N})$ nutrition for pecan production.
\end{abstract}

Recently, rising energy costs have led to a dramatic increase in the price of synthetic fertilizer (Huang, 2009). Between 2002 and 2007 the cost of synthetic fertilizer N per acre rose by over $200 \%$ for pecan (Wells, 2009a). This sharp increase in the cost of a single input dramatically reduces the profit margin for pecan producers. Legumes and manure, produced by cattle grazing the orchards, were commonly used to provide fertilizer $\mathrm{N}$ for pecan trees in the early years of the southeastern pecan industry. Synthetic fertilizers were readily available at affordable prices after World War II, which led to their widescale use, replacing legumes and manure as nutrient sources for pecans (White et al., 1981). As air-blast sprayers were developed and put into use for pesticide application, grazing cattle in the orchard was discontinued in many areas.

Rising $\mathrm{N}$ fertilizer costs have led pecan producers to once again consider the use of various legumes such as crimson clover as an orchard floor cover to supplement tree $\mathrm{N}$ requirements. Smith et al. (1996) suggested

Received for publication 21 Mar. 2012. Accepted for publication 14 May 2012.

This work was supported by the Georgia Agricultural Commodity Commission for Pecans.

I thank Del Taylor, Mike Crumley, Mike Hudson, and Cody Casey for technical assistance.

${ }^{1}$ To whom reprint requests should be addressed; e-mail1wells@uga.edu. that a combination of crimson clover and hairy vetch (Vicia villosa Roth) could be used as a cover crop to meet the $\mathrm{N}$ requirement of pecan in Oklahoma; however, little research in this regard has been conducted in the southeastern United States. Wells (2011a) suggested that crimson clover could provide up to $75 \mathrm{~kg} \cdot \mathrm{ha}^{-1} \mathrm{~N} 2$ years after establishment, although it was not available until late in the growing season. In 2005, clover (Trifolium sp.) was used in only $15 \%$ of surveyed pecan orchards in Georgia. By 2008, nearly half of all pecan orchards surveyed used clover as an orchard floor cover (Wells, 2009b).

Georgia poultry farmers produce over 10.2 million tons of poultry litter annually in the production of meat and eggs, generating $\approx 20 \%$ of the poultry litter produced in the United States (Dunkley et al., 2011). Proper application of litter to the land as a soil amendment is an appropriate use for the waste product. The organic material and nutrients found in poultry litter are beneficial byproducts that have proven useful in amending agricultural soils (Mitchell and Tu, 2005).

The response of $\mathrm{N}$ availability and chemical and biological soil quality indicators to poultry litter and clover use in pecan orchards has been previously reported (Wells, 2011a, 2011b); however, significant questions persist regarding the overall effects of poultry litter and clover on pecan tree nutrition and production. The objective of this study was to investigate the effects of these nutrient sources on orchard soil, horticultural, and nut quality parameters of pecan in the southeastern United States.

\section{Materials and Methods}

Study site, experimental design, soil sampling. The study was conducted in a 25 year-old solid-set sprinkler-irrigated pecan orchard on a $12.2 \mathrm{~m} \times 12.2 \mathrm{-m}$ spacing located at the University of Georgia Tifton Campus Ponder Research Farm near Tifton, GA, from 2008 to 2011. Soil type was Fuquay loamy sand (loamy, siliceous, thermic Arenic Plinthic Paleudult). The orchard was managed under commercial conditions according to University of Georgia Cooperative Extension recommendations (Hudson et al., 2011). A 3.7-m-wide vegetation free strip was maintained with glyphosate along the tree row in all plots. Row middles consisted of bermudagrass (Cynodon dactylon L.) sod only except as indicated subsequently. The following treatments were evaluated: 1) crimson clover; 2) poultry litter; 3) crimson clover + poultry litter; 4) ammonium nitrate; and 5) untreated control (2009 to 2011). Treatments were arranged in a randomized complete block design using six replications. Blocks were arranged with each treatment represented once per block. Each plot consisted of a $24.4 \mathrm{~m} \times 24.4-\mathrm{m}$ area centered on a single pecan tree. All plots were separated by untreated border plots. Individual plots received the same treatments during each year of the study.

Rhizobium-inoculated 'Dixie' crimson clover was broadcast-seeded annually over the bermudagrass sodded row middles with no ground prep each fall beginning in Oct. 2007 at a rate of $33.6 \mathrm{~kg} \cdot \mathrm{ha}^{-1}$ to ensure a full stand in the crimson clover and crimson clover + poultry litter plots. Clover stand density was not measured; however, visual observation suggests that a full stand of clover was obtained. Non-composted, dry poultry (broiler) litter was applied at a rate of $2240 \mathrm{~kg} \cdot \mathrm{ha}^{-1}$ $\left(\approx 150 \mathrm{~kg} \cdot \mathrm{ha}^{-1} \mathrm{~N}\right)$ on $31 \mathrm{Mar}$. 2008, $31 \mathrm{Mar}$. 2009, 29 Mar. 2010, and 28 Mar. 2011. This rate is reflective of that traditionally used by pecan growers in the southeastern United States. Poultry litter analysis for each year of study can be found in Table 1. Poultry litter was stored in a roofed stackhouse for $45 \mathrm{~d}$ before application. Ammonium nitrate $(34 \mathrm{~N}-$ 0P-0K) was applied uniformly over the $595-\mathrm{m}^{2}$ plot at a rate of $84 \mathrm{~kg} \cdot \mathrm{ha}^{-1} \mathrm{~N}$ on $31 \mathrm{Mar} .2008$, 31 Mar. 2009, 29 Mar. 2010, and 28 Mar. 2011. This rate is considered a sufficient rate of $\mathrm{N}$ for southeastern pecan production because yield responses to higher rates are rarely observed in managed orchards (Worley, 2002). Zinc sulfate $\left(62.9 \mathrm{~kg} \cdot \mathrm{ha}^{-1}\right)(36 \% \mathrm{Zn})$ and muriate of potash $\left(70.6 \mathrm{~kg} \cdot \mathrm{ha}^{-1}\right)(52 \% \mathrm{~K})$ were applied to all plots on 23 Mar. 2009. Plots with clover or poultry litter did not receive $\mathrm{N}$ from other fertilizer sources. All clover residue, poultry litter, and fertilizer were left undisturbed on the soil surface after application. The untreated control received no $\mathrm{N}$ fertilizer inputs.

Foliage was sampled in late July of each study year by collecting 30 leaflet pairs per 
tree. All leaflet samples were taken from the middle leaf of sun-exposed terminals. Leaflet samples were washed in a dilute phosphatefree detergent solution $(0.1 \%$ detergent $)$ followed by rinsing with deionized water. Leaves were then dried to a constant weight at $80^{\circ} \mathrm{C}$ and ground in a Wiley Mill (Wiley, Philadelphia, PA) to pass a 1-mm screen. Leaves for $\mathrm{N}$ analysis were also ground with a mortar and pestle. Samples were analyzed for N by combustion using a Leco FP528 protein/N determinator (Leco Corp., St. Joseph, MI), whereas remaining nutrients [calcium $(\mathrm{Ca})$, magnesium (Mg), K, P, sulfur (S), boron (B), $\mathrm{Zn}, \mathrm{Fe}$, manganese $(\mathrm{Mn})$, and $\mathrm{Cu}$ ] were measured by an inductive coupled plasma spectrophotometer (ICP) coupled to a Digiblock 3000 (SCP Science, Baie D'Urfé, Quebec, Canada).

A composite soil sample at $0 \mathrm{~cm}$ to $15.2-\mathrm{cm}$ depth with the surface $2.54 \mathrm{~cm}$ removed was taken from the vegetated area under the dripline of each tree. Four cores per tree were combined for an individual sample per plot. Soil was dried and analyzed for $\mathrm{pH}, \mathrm{P}, \mathrm{K}, \mathrm{Ca}$,

Table 1. Mineral analysis of dry poultry litter used during 2008, 2009, 2010, and 2011. ${ }^{\mathrm{z}}$

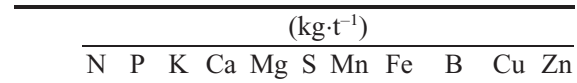
\begin{tabular}{lllllllllllll}
\hline 2008 & 37 & 8 & 15 & 15 & 3 & 3 & 0.2 & 0.6 & 0.01 & 0.2 & 0.2
\end{tabular} $\begin{array}{llllllllllll}2009 & 31 & 31 & 34 & 24 & 6 & 6 & 0.2 & 2 & 0.03 & 0.4 & 0.3\end{array}$ $\begin{array}{llllllllllll}2010 & 30 & 30 & 33 & 22 & 6 & 6 & 0.2 & 2 & 0.02 & 0.4 & 0.3\end{array}$ $\begin{array}{llllllllllll}2011 & 31 & 31 & 33 & 22 & 6 & 6 & 0.2 & 3 & 0.03 & 0.4 & 0.3\end{array}$ ${ }^{\mathrm{z}}$ Measured nutrients were total (organic and inorganic) nitrogen $(\mathrm{N})$, phosphorous $(\mathrm{P})$, potassium $(\mathrm{K})$, magnesium $(\mathrm{Mg})$, calcium $(\mathrm{Ca})$, sulfur $(\mathrm{S})$, manganese $(\mathrm{Mn})$, iron $(\mathrm{Fe})$, boron $(\mathrm{B})$, copper $(\mathrm{Cu})$, and zinc $(\mathrm{Zn})$.
$\mathrm{Mg}, \mathrm{Mn}, \mathrm{Fe}$, and $\mathrm{S}$. Soil $\mathrm{pH}$ was determined in a $0.01 \mathrm{M}$ calcium chloride $\left(\mathrm{CaCl}_{2}\right)$ solution using a LabFit AS-3000 (Labfit, Perth, Australia) dual $\mathrm{pH}$ analyzer. Soil $\mathrm{P}, \mathrm{K}, \mathrm{Ca}, \mathrm{Mg}$, $\mathrm{Mn}, \mathrm{Fe}$, and $\mathrm{S}$ were determined by ICP.

At harvest, yield was estimated by shaking trees and measuring the weight of nuts in a wedge-shaped grid consisting of $1 / 100$ of the area beneath the tree (Conner and Worley, 2000). Four subsample grids were used per tree, the weight summed, and multiplied by 25 to obtain the total tree yield. Only non-germinated, marketable nuts were used to measure yield. A 50-nut sample was collected from each tree for analysis of individual nut weight and percent kernel. Nuts were shelled and percentage of edible kernel was calculated by dividing the kernel weight for the 50-nut sample by total nut weight.

Fluctuation in yield was expressed in terms of alternate bearing $I$, calculated as: $I=1 /(n-1) \times\left\{\left|\left(\mathrm{Y}_{1}-\mathrm{Y}_{2}\right)\right| /\left(\mathrm{Y}_{1}+\mathrm{Y}_{2}\right)+\mid\left(\mathrm{Y}_{2}-\right.\right.$ $\left.\mathrm{Y}_{3}\right)\left|/\left(\mathrm{Y}_{2}+\mathrm{Y}_{3}\right)+\ldots\right|\left(\mathrm{Y}_{n-1}-\mathrm{Y} n\right) \mid /(\mathrm{Y} n-1+$ $\mathrm{Y} n)\}$, where $n=$ number of years and $\mathrm{Y}=$ tree yield for the corresponding year (Pearce and Dobersek-Urbanc, 1967).

Statistical analyses of data were performed with SAS (SAS Institute, Cary, NC). Analysis of variance was used to compare treatment effects. Means were separated using Duncan's multiple range test $(P<0.05)$ (Wells, 2011a, 2011b).

\section{Results}

Pecan leaf tissue and orchard soil elemental analysis. Leaf $\mathrm{N}$ was affected by treatment in only the final year of study when leaf $\mathrm{N}$ was lower in the control treatment than all other treatments (Table 2). Leaf $\mathrm{P}$ was higher in the poultry litter, poultry litter + clover, and control plots in 2009. In 2011, poultry litter and poultry litter + clover had higher leaf $\mathrm{P}$ than the remaining treatments. Leaf $\mathrm{K}$ was reduced in the clover treatment during 2008. Leaf $\mathrm{K}$ was reduced by all treatments except clover + poultry litter in 2010 as compared with the control. In 2011, leaf $\mathrm{K}$ was higher in the clover + litter treatment than in the ammonium nitrate and clover treatments. The clover treatment reduced leaf $\mathrm{K}$ as compared with the control.

Treatment effects on leaf $\mathrm{Ca}$ were varied among years (Table 2). In 2009, leaf Ca was higher in the clover treatment than in the ammonium nitrate treatment. Ammonium nitrate increased leaf $\mathrm{Ca}$ in 2010, whereas leaf $\mathrm{Ca}$ was reduced in the clover treatment during 2011. Leaf $\mathrm{Mg}$ was higher in the poultry litter treatment during 2008. In 2009, plots receiving poultry litter had higher leaf $\mathrm{Mg}$ than the control and ammonium nitrate treatments. Leaf S was highest in the clover + litter treatment in 2009. In 2011, leaf $\mathrm{S}$ concentration was reduced in the clover treatment as compared with the poultry litter and clover + poultry litter treatments. Leaf Mn was higher in the clover treatment as compared with all other treatments in 2009.

Leaf Fe was influenced by treatment in 3 of 4 years. In 2009 and 2010, the clover + litter treatment resulted in the highest leaf Fe. Leaf $\mathrm{Fe}$ was highest in those plots in which clover grew in 2011 (Table 2). The clover treatment reduced leaf $\mathrm{B}$ concentration in 3 of 4 years. Poultry litter application led to an

Table 2. Effect of clover, poultry litter, clover + poultry litter, ammonium nitrate and control treatments on pecan leaf elemental tissue concentration from 2008 to 2011.

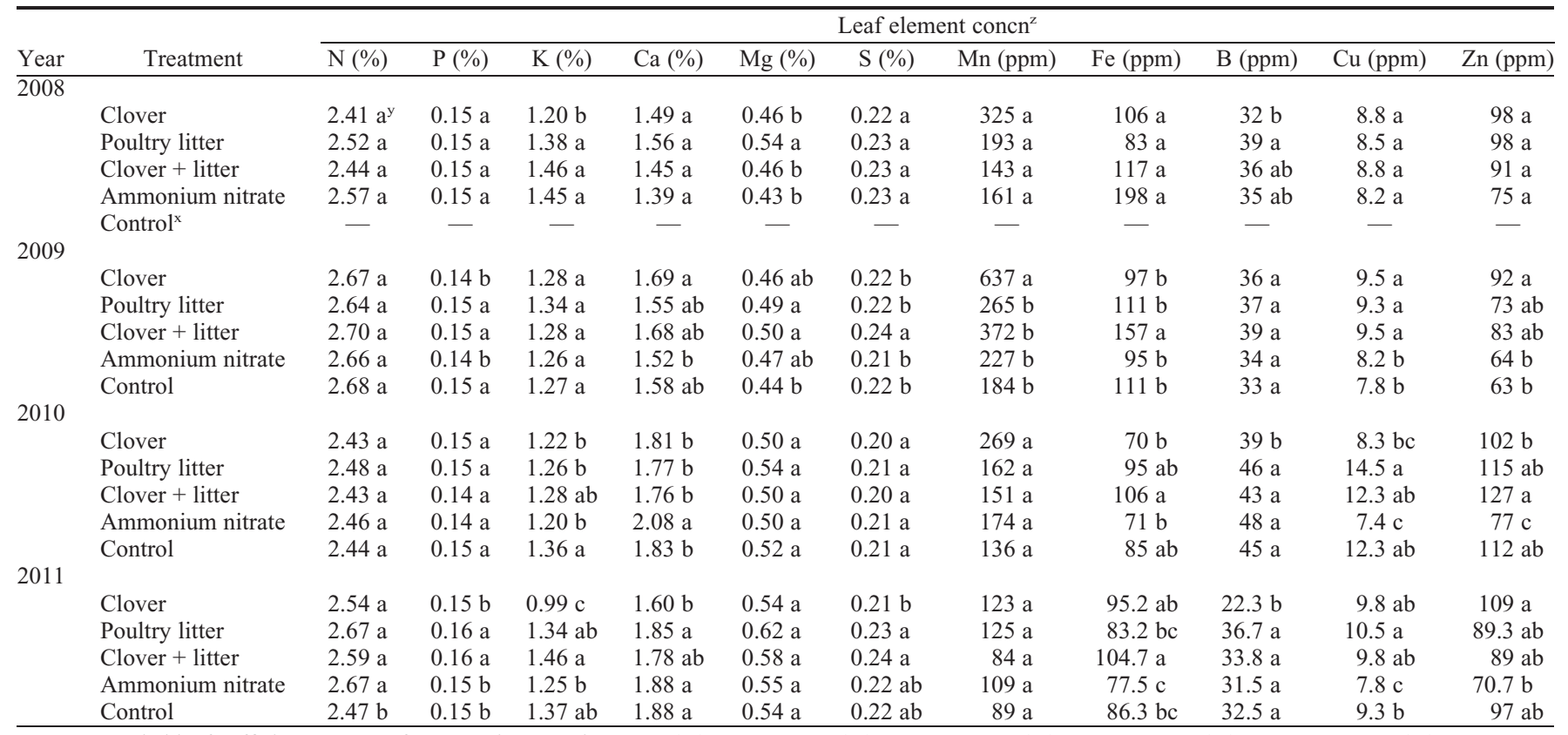

${ }^{\mathrm{z}}$ Recommended leaf sufficiency ranges for pecan in Georgia are: $\mathrm{N}(\%)=2.5-3.0 ; \mathrm{P}(\%)=0.14-0.3 ; \mathrm{K}(\%)=1.3-2.5 ; \mathrm{Ca}(\%)=1.3-1.75 ; \mathrm{Mg}(\%)=0.35-0.6$; $\mathrm{S}(\%)$ 0.25-0.5; Mn $(\mathrm{ppm})=100-800 ; \mathrm{Fe}(\mathrm{ppm})=50-300 ; \mathrm{B}(\mathrm{ppm})=50-100 ; \mathrm{Cu}(\mathrm{ppm})=6-30 ; \mathrm{Zn}(\mathrm{ppm})=50-100$ (Wells, 2007).

${ }^{\mathrm{y}}$ Means followed by the same letter within each year are not different at $P<0.05$ by Duncan's multiple range test.

${ }^{\mathrm{x}}$ The untreated control treatment was added to the study in 2009.

$\mathrm{N}=$ nitrogen; $\mathrm{P}=$ phosphorus; $\mathrm{K}=$ potassium; $\mathrm{Ca}=$ calcium; $\mathrm{Mg}=$ magnesium; $\mathrm{S}=$ sulfur; $\mathrm{Mn}=$ manganese; $\mathrm{Fe}=$ iron; $\mathrm{B}=$ boron; $\mathrm{Cu}=$ copper; $\mathrm{Zn}=$ zinc. 
increase in leaf $\mathrm{Cu}$ concentration in 2009, 2010, and 2011. Ammonium nitrate application reduced leaf $\mathrm{Cu}$ concentration in 2010 and 2011 compared with that of the control. Pecan leaf $\mathrm{Zn}$ concentration was higher in the clover treatment than in the ammonium nitrate and control treatments during 2009. Leaf $\mathrm{Zn}$ concentration was lowest in the ammonium nitrate treatment in 2010 and 2011.

Pecan orchard soil elemental analysis. Soil $\mathrm{P}$ was higher in the poultry litter and clover + litter treatments than in the remaining treatments during each year of study (Table 3). Soil K was higher in the poultry litter treatment when compared with all other treatments in 2008. In 2009, soil K was higher in the poultry litter treatment than in the clover and control treatments. During 2010, soil K was higher in the clover + litter treatment than in the ammonium nitrate or control treatments. Magnesium was higher in the poultry litter treatment than in the clover and ammonium nitrate treatments during the first 2 years of study. During 2011, soil Mg was higher in the control treatment than in the poultry litter, clover + litter, and ammonium nitrate treatments. Soil Mn was highest in the poultry litter treatment during 2008. In 2009, poultry litter with and without clover led to higher soil Mn levels than clover or ammonium nitrate. Soil $\mathrm{Mn}$ was higher in the poultry litter treatment than in the ammonium nitrate treatment during 2010. In 2011, soil Mn was higher in the clover + litter treatment than in the ammonium nitrate and control treatments. Although soil Fe was not measured during the first 2 years of study, the clover + litter treatment had higher soil $\mathrm{Fe}$ than in the clover, poultry litter, and ammonium nitrate treatments in 2010. During the same year, soil $\mathrm{Cu}$ was higher in the poultry litter treatment than in the clover, ammonium nitrate, and control treatments. Soil $\mathrm{Cu}$ was higher in the clover + litter treatment than in all other treatments during 2011. Soil Zn was higher in the poultry litter treatment than in all other treatments during 2008. No treatment differences were observed for soil $\mathrm{pH}$ (data not shown), which ranged from 6.3 to 6.4 in $2008,6.2$ to 6.5 in 2009, 5.3 to 6.9 in 2010, and 7.0 to 7.3 in 2011.

Pecan yield, quality, and alternate bearing intensity. There was no treatment effect on percent kernel throughout the study. During 2009 , nut weight was greater in the poultry litter treatment than in the clover + litter and ammonium nitrate treatments (Table 4). Yield effects were observed for treatments beginning in 2009. Yields for the ammonium nitrate and control treatments were higher than those of the clover and clover + litter treatments in 2009. There were no yield differences between the ammonium nitrate and poultry litter treatments throughout the study. During 2010 and 2011, yield for the clover + litter treatment was higher than that for the control treatment.

Alternate bearing $I$ ranged from 0.05 to 0.35 for the clover treatment, from 0.14 to 0.48 for poultry litter, from 0.02 to 0.35 for

Table 3. Effect of clover, poultry litter, clover + poultry litter, ammonium nitrate and control treatments on soil elemental analysis.

\begin{tabular}{|c|c|c|c|c|c|c|c|c|c|}
\hline \multirow{3}{*}{$\frac{\text { Year }}{2008}$} & \multirow[b]{2}{*}{ Treatment } & \multicolumn{8}{|c|}{ Soil analysis $\left(\mathrm{kg} \cdot \mathrm{ha}^{-1}\right)$} \\
\hline & & $\mathrm{P}$ & $\mathrm{K}$ & $\mathrm{Ca}$ & $\mathrm{Mg}$ & $\mathrm{Mn}$ & $\mathrm{Fe}$ & $\mathrm{Cu}$ & $\mathrm{Zn}$ \\
\hline & & & & & & & & & \\
\hline & Clover & $63 c^{z}$ & $73 \mathrm{c}$ & $1775 \mathrm{a}$ & $287 \mathrm{~b}$ & $13 \mathrm{bc}$ & - & - & $40 \mathrm{~b}$ \\
\hline & Poultry litter & $248 \mathrm{a}$ & $194 \mathrm{a}$ & $2201 \mathrm{a}$ & $408 \mathrm{a}$ & $18.3 \mathrm{a}$ & - & - & $60 \mathrm{a}$ \\
\hline & Clover + litter & $136 \mathrm{~b}$ & $133 \mathrm{~b}$ & $1941 \mathrm{a}$ & $342 \mathrm{ab}$ & $14.9 \mathrm{~b}$ & - & - & $45 \mathrm{~b}$ \\
\hline & Ammonium nitrate & $78 \mathrm{c}$ & $92 \mathrm{bc}$ & $1886 \mathrm{a}$ & $311 \mathrm{~b}$ & $11.3 \mathrm{c}$ & - & - & $45 \mathrm{~b}$ \\
\hline & Control $^{\mathrm{y}}$ & - & - & - & - & - & - & - & - \\
\hline \multicolumn{10}{|l|}{2009} \\
\hline & Clover & $25 \mathrm{~b}$ & $36 \mathrm{~b}$ & $971 \mathrm{a}$ & $134 \mathrm{~b}$ & $5.6 \mathrm{bc}$ & - & $0.15 \mathrm{a}$ & $17 \mathrm{~b}$ \\
\hline & Poultry litter & 59 a & $63 \mathrm{a}$ & $1148 \mathrm{a}$ & 169 a & $7.0 \mathrm{a} \mathrm{a}$ & - & $0.29 \mathrm{a}$ & $20 \mathrm{~b}$ \\
\hline & Clover + litter & $67 \mathrm{a}$ & $53 \mathrm{ab}$ & $1044 \mathrm{a}$ & $145 \mathrm{ab}$ & $6.6 \mathrm{ab}$ & - & $0.31 \mathrm{a}$ & $19 \mathrm{~b}$ \\
\hline & Ammonium nitrate & $35 \mathrm{~b}$ & $50 \mathrm{ab}$ & $952 \mathrm{a}$ & $135 \mathrm{~b}$ & $5.3 \mathrm{c}$ & - & $0.20 \mathrm{a}$ & $17 \mathrm{~b}$ \\
\hline & Control & $37 \mathrm{~b}$ & $46 \mathrm{~b}$ & $1093 \mathrm{a}$ & $152 \mathrm{ab}$ & $5.6 \mathrm{bc}$ & - & $0.18 \mathrm{a}$ & $26 \mathrm{a}$ \\
\hline \multicolumn{10}{|l|}{2010} \\
\hline & Poultry litter & $121 \mathrm{a}$ & $28 \mathrm{ab}$ & $1221 \mathrm{a}$ & $153 \mathrm{a}$ & $9.3 \mathrm{a}$ & $6.2 \mathrm{~b}$ & $0.88 \mathrm{a}$ & $32 \mathrm{a}$ \\
\hline & Clover + litter & $101 \mathrm{a}$ & $30 \mathrm{a}$ & $1096 \mathrm{a}$ & $141 \mathrm{a}$ & $8.7 \mathrm{ab}$ & $12.9 \mathrm{a}$ & $0.80 \mathrm{ab}$ & $32 \mathrm{a}$ \\
\hline & Ammonium nitrate & $46 \mathrm{~b}$ & $22 \mathrm{~b}$ & $947 \mathrm{a}$ & $110 \mathrm{a}$ & $6.8 \mathrm{~b}$ & $5.4 \mathrm{~b}$ & $0.27 \mathrm{c}$ & $30 \mathrm{a}$ \\
\hline & Control & $50 \mathrm{~b}$ & $23 \mathrm{~b}$ & $1164 \mathrm{a}$ & $150 \mathrm{a}$ & $7.9 \mathrm{ab}$ & $8.7 \mathrm{ab}$ & $0.43 \mathrm{bc}$ & $40 \mathrm{a}$ \\
\hline \multicolumn{10}{|l|}{2011} \\
\hline & Clover & $62 \mathrm{~b}$ & $75 \mathrm{a}$ & $2705 \mathrm{a}$ & $307 \mathrm{ab}$ & $17 \mathrm{ab}$ & $2.5 \mathrm{a}$ & $0.22 \mathrm{~b}$ & $60 \mathrm{a}$ \\
\hline & Clover + litter & $148 \mathrm{a}$ & $\begin{array}{l}106 \mathrm{a} \\
100 \mathrm{a}\end{array}$ & $2501 \mathrm{a}$ & $\begin{array}{l}284 \mathrm{~b} \\
287 \mathrm{~b}\end{array}$ & $\begin{array}{l}17 \mathrm{ab} \\
24 \mathrm{a}\end{array}$ & $\begin{array}{l}4.2 \mathrm{a} \\
3.0 \mathrm{a}\end{array}$ & $\begin{array}{l}0.63 \mathrm{~b} \\
1.10 \mathrm{a}\end{array}$ & $\begin{array}{l}43 \mathrm{a} \\
43 \mathrm{a}\end{array}$ \\
\hline & Ammonium nitrate & $62 \mathrm{~b}$ & $91 \mathrm{a}$ & $2128 \mathrm{a}$ & $267 \mathrm{~b}$ & $13 \mathrm{~b}$ & $2.2 \mathrm{a}$ & $0.22 \mathrm{~b}$ & $47 \mathrm{a}$ \\
\hline & Control & $63 \mathrm{~b}$ & $71 \mathrm{a}$ & $2645 a$ & 392 a & $12 \mathrm{~b}$ & $3.4 \mathrm{a}$ & $0.22 \mathrm{~b}$ & $45 \mathrm{a}$ \\
\hline
\end{tabular}

${ }^{\mathrm{z}}$ Means followed by the same letter within each year are not different at $P<0.05$ by Duncan's multiple range test.

yThe untreated control treatment was added to the study in 2009.

$\mathrm{P}=$ phosphorus $\mathrm{K}=$ potassium $; \mathrm{Ca}=$ calcium $; \mathrm{Mg}=$ magnesium; $\mathrm{Mn}=$ manganese $; \mathrm{Fe}=$ iron $; \mathrm{Cu}=$ copper; $\mathrm{Zn}=$ zinc.

Table 4. Effect of clover, poultry litter, clover + poultry litter, ammonium nitrate and control treatments on percent kernel, nuts $/ \mathrm{kg}$, and pecan yield from 2008-2011.

\begin{tabular}{llccc}
\hline Year & \multicolumn{1}{c}{ Treatment } & Percent kernel (\%) & Nut wt (g) & Yield (kg per tree) \\
\hline 2008 & & & & \\
& Clover & $53.3 \mathrm{a}^{\mathrm{z}}$ & $8.51 \mathrm{a}$ & $43.0 \mathrm{a}$ \\
& Poultry litter & $54.0 \mathrm{a}$ & $8.42 \mathrm{a}$ & $42.1 \mathrm{a}$ \\
& Clover + litter & $52.0 \mathrm{a}$ & $8.73 \mathrm{a}$ & $39.5 \mathrm{a}$ \\
& Ammonium nitrate & $52.4 \mathrm{a}$ & $8.66 \mathrm{a}$ & $28.2 \mathrm{a}$ \\
& Control & - & - \\
& & - & $9.36 \mathrm{ab}$ & $39.3 \mathrm{~b}$ \\
& Clover & $50.8 \mathrm{a}$ & $9.88 \mathrm{a}$ & $55.5 \mathrm{ab}$ \\
& Poultry litter & $51.7 \mathrm{a}$ & $8.32 \mathrm{~b}$ & $37.9 \mathrm{~b}$ \\
& Clover + litter & $50.3 \mathrm{a}$ & $8.47 \mathrm{~b}$ & $58.8 \mathrm{a}$ \\
& Ammonium nitrate & $52.1 \mathrm{a}$ & $9.34 \mathrm{ab}$ & $59.2 \mathrm{a}$ \\
& Control & $52.6 \mathrm{a}$ & & \\
& & & $11.88 \mathrm{a}$ & $19.0 \mathrm{ab}$ \\
& Clover & $50.7 \mathrm{a}$ & $10.83 \mathrm{a}$ & $19.3 \mathrm{ab}$ \\
& Poultry litter & $50.2 \mathrm{a}$ & $10.76 \mathrm{a}$ & $23.3 \mathrm{a}$ \\
& Clover + litter & $49.7 \mathrm{a}$ & $10.70 \mathrm{a}$ & $17.0 \mathrm{ab}$ \\
& Ammonium nitrate & $49.7 \mathrm{a}$ & $11.53 \mathrm{a}$ & $7.7 \mathrm{~b}$ \\
& Control & $52.3 \mathrm{a}$ & & \\
& & & $11.22 \mathrm{a}$ & $26.1 \mathrm{ab}$ \\
& Clover & $53.7 \mathrm{a}$ & $10.74 \mathrm{a}$ & $38.6 \mathrm{ab}$ \\
& Poultry litter & $52.2 \mathrm{a}$ & $11.09 \mathrm{a}$ & $47.9 \mathrm{a}$ \\
& Clover + litter & $53.8 \mathrm{a}$ & $10.86 \mathrm{a}$ & $42.1 \mathrm{ab}$ \\
& Ammonium nitrate & $54.0 \mathrm{a}$ & $11.38 \mathrm{a}$ & $23.5 \mathrm{~b}$ \\
\hline
\end{tabular}

${ }^{\mathrm{z}}$ Means followed by the same letter within each year are not different at $P<0.05$ by Duncan's multiple range test.

${ }^{y}$ The untreated control treatment was added to the study in 2009.

poultry litter + clover, from 0.35 to 0.55 for ammonium nitrate, and from 0.51 to 0.77 for the control (Table 5). Alternate bearing $I$ was consistently lower in the clover treatment than in the ammonium nitrate and control treatments. When all 4 years of study were included in the calculations, clover, poultry litter, and clover + poultry litter had lower I than did the control.

\section{Discussion}

Leaf elemental tissue analysis, pecan yield, and quality indicate that poultry litter and clover provide adequate $\mathrm{N}$ nutrition for pecan production. Previous studies have shown an obvious time lag between poultry litter application and maximum $\mathrm{N}$ fixation in clover and availability of $\mathrm{N}$ for pecan trees 
Table 5 . Alternate bearing intensity $(I)^{z}$ of 'Desirable' pecan trees for clover, poultry litter, clover + poultry litter, ammonium nitrate, and control treatments from 2008 to 2011.

\begin{tabular}{lcccc}
\hline Treatment & $2008-2009$ & $2009-2010$ & $2010-2011$ & $2008-2011$ \\
\hline Clover & $0.05 \mathrm{~b}^{\mathrm{y}}$ & $0.35 \mathrm{~b}$ & $0.16 \mathrm{~b}$ & $0.18 \mathrm{c}$ \\
Poultry litter & $0.14 \mathrm{ab}$ & $0.48 \mathrm{ab}$ & $0.33 \mathrm{ab}$ & $0.31 \mathrm{~b}$ \\
Clover + poultry litter & $0.02 \mathrm{~b}$ & $0.24 \mathrm{~b}$ & $0.35 \mathrm{ab}$ & $0.20 \mathrm{bc}$ \\
Ammonium nitrate & $0.35 \mathrm{a}$ & $0.55 \mathrm{a}$ & $0.43 \mathrm{a}$ & $0.43 \mathrm{ab}$ \\
Control $^{\mathrm{x}}$ & - & $0.77 \mathrm{a}$ & $0.51 \mathrm{a}$ & $0.64 \mathrm{a}$ \\
\hline
\end{tabular}

${ }^{\mathrm{Z}} \mathrm{I}=1 /(\mathrm{n}-1) \times\{|(\mathrm{Y} 1-\mathrm{Y} 2)| /(\mathrm{Y} 1+\mathrm{Y} 2)+|(\mathrm{Y} 2-\mathrm{Y} 3)| /(\mathrm{Y} 2+\mathrm{Y} 3)+\ldots|(\mathrm{Y} n-1-\mathrm{Yn})| /(\mathrm{Y} n-1+\mathrm{Yn})\}$, where $\mathrm{n}=$ number of years and $Y=$ tree yield for the corresponding year (Pearce and Dobersek-Urbanc, 1967).

${ }^{y}$ Means followed by the same letter are not different at $P<0.05$ by Duncan's multiple range test.

${ }^{x}$ The untreated control treatment was added to the study in 2009 .

(Wells, 2011a). Poultry litter application has been associated with excessive $\mathrm{N}$ accumulation in some cropping systems, resulting in potential contamination of surface and subsurface drainage water through nitrate leaching (Kingery et al., 1994). Wells (2011a) demonstrated that poultry litter application did not increase total available soil $\mathrm{N}$ as compared with synthetic fertilizer application in the upper $20.5 \mathrm{~cm}$ of the soil profile in a pecan orchard system. Furthermore, the safety-net hypothesis assumes that trees in agroforestry systems are capable of recycling soil nutrients that leach downward in the soil profile, thereby reducing groundwater contamination and increasing nutrient use efficiency in the system (Rowe et al., 1999). Allen et al. (2004) demonstrated that pecan tree roots reduced $\mathrm{N}$ leaching in a cotton-pecan alley-cropping system, partially as a result of tree water uptake, which reduced soil water drainage and $\mathrm{N}$ leaching. Thus, pecan orchard systems may be less susceptible to $\mathrm{N}$ leaching than are other cropping systems.

In addition to $\mathrm{N}$, poultry litter supplies many other essential nutrients for pecan. Application of poultry litter with or without clover often led to higher soil P and K (Table $3)$. Excess soil $\mathrm{P}$ accumulation is often a serious concern with poultry litter application as a result of the potential for surface runoff and pollution (Havlin et al., 2005). Although always a concern, there would likely be a reduced potential for $\mathrm{P}$ runoff in the pecan orchard system as managed in the southeastern United States as compared with other cropping systems because the orchard floor is maintained with grass alleyways between the tree rows. Although $\mathrm{P}$ is relatively immobile in the soil environment, as mentioned previously, deep-rooted orchard crops such as pecan can play a significant safety-net role in the alleviation of excessive nutrient loss (Allen et al., 2004). Where $P$ is concerned, pecan roots may also help to stabilize soil, minimizing soil erosion and $\mathrm{P}$ runoff into streams. The addition of clover to this system would further reduce the likelihood of surface runoff because clover is actively growing at the time of poultry litter application and uses some of the $\mathrm{P}$ and other nutrients from the litter. Pecan leaf $P$ concentration remained unaffected by poultry litter until the final year of study, indicating that pecan can use the excess $P$ supplied by the poultry litter, although quantitative observation may be delayed by the associated time lag between application and any increase in leaf $\mathrm{P}$ concentration.
Soil K was unaffected by clover as compared with the control (Table 3); however, pecan leaf $\mathrm{K}$ was reduced by the clover treatment in each year of study, except 2009, in which additional $\mathrm{K}$ was applied to all treatments (Table 2). This may have been the result of use of available $\mathrm{K}$ by the clover itself, making less available for the pecan trees. Adams et al. (1967) reported a lower K content in bermudagrass forage when crimson clover was grown in association, suggesting that the soil was unable to supply enough $\mathrm{K}$ to offset the competition between the bermudagrass and clover. During the current study, poultry litter apparently provided an adequate supply of $\mathrm{K}$ for both the pecan trees and the clover in Year 4 because pecan leaf $K$ concentration was higher for the clover + litter treatment than for clover alone. The recurring low pecan leaf $\mathrm{K}$ in the presence of clover without additional $\mathrm{K}$ application suggests that $\mathrm{K}$ nutrition may be especially important in orchards where clover is used.

Treatment effects on soil organic matter (SOM) from the current study have been previously reported and suggest that clover and poultry litter alone and in combination increased SOM (Wells, 2011b). Sparks (2005) indicates that the high level of organic matter found in the pecan's native habitat provides an abundant nutrient supply, including $\mathrm{S}, \mathrm{Cu}$, and $\mathrm{Zn}$, to which the tree has adapted. Thus, it is likely that the addition of organic matter to the orchard soil in the form of clover and poultry litter have played a role in enhancing nutrient availability for pecan over the long term.

Leaf $\mathrm{S}$ concentration is commonly observed to be low (less than $0.25 \%$ ) in many southeastern U.S. pecan orchards (Wells, 2009 b). The current study suggests that poultry litter with and without clover can occasionally enhance pecan leaf $\mathrm{S}$ concentration. Poultry litter supplied from 3 to $6 \mathrm{~kg} \cdot \mathrm{t}^{-1} \mathrm{~S}$ annually (Table 1); however, treatment effects were only observed in 2 of the 4 years of study (Table 2). Sulfur availability is affected by a variety of factors, including SOM, temperature, rainfall, soil moisture, and soil $\mathrm{pH}$. Many of these factors may vary from 1 year to the next and could have resulted in variable uptake of the additional $\mathrm{S}$ provided by the poultry litter.

Clover and/or clover + litter occasionally led to enhanced leaf concentrations of $\mathrm{Fe}, \mathrm{Cu}$, and $\mathrm{Zn}$, particularly after the first year of study (Table 2). The accumulation of these heavy metals is often a concern where poultry litter is applied to agricultural land (Kingery et al., 1994). However, pecans have a relatively high requirement for these elements and may benefit from their application (Sparks, 2005). As a result, poultry litter can be a good source of $\mathrm{Fe}, \mathrm{Cu}$, and $\mathrm{Zn}$ for pecan. Iron deficiencies in pecan normally occur early in the season and often clear up as the season progresses. Leaf Fe concentration was within the recommended range (50 to $300 \mathrm{ppm}$ ) (Wells, 2007) for all treatments; however, the clover + litter treatment consistently increased leaf Fe after Year 1. Similarly, pecan leaf $\mathrm{Cu}$ was enhanced by poultry litter application after Year 1. Clover and clover + litter also occasionally led to higher leaf $\mathrm{Cu}$ concentrations. Van Lam et al. (1978) reported that uptake of $\mathrm{Cu}$ by pecan was slow and that significant uptake was not observed until the third year after application. The current recommended pecan leaf sufficiency range for $\mathrm{Cu}$ is 6 to $30 \mathrm{ppm}$ for pecan in Georgia (Wells, 2007); however, Sparks (1989) has suggested a leaf sufficiency range of 10 to $15 \mathrm{ppm} \mathrm{Cu}$ for pecan. Although leaf $\mathrm{Cu}$ was within the current recommended range for all treatments, only poultry litter increased leaf $\mathrm{Cu}$ to the 10 to 15 -ppm range suggested by Sparks (1989).

Zinc deficiency is the most widespread and commonly observed nutritional deficiency of pecan (Sparks, 1989). Zinc is required for shoot elongation and leaf expansion. Also, because $\mathrm{Zn}$ deficiency results in incomplete shoot development of pecan, yield is drastically reduced (Sparks, 1989). Nunez-Moreno et al. (2009) found that cow manure increased pecan leaf $\mathrm{Zn}$ concentration 3 years after application began. During the current study, treatment effects on leaf $\mathrm{Zn}$ were observed each year after study Year 1; however, poultry litter failed to increase leaf $\mathrm{Zn}$ over that of the control except in the presence of clover in 2010 (Table 2). Although additional $\mathrm{Zn}$ was applied to all treatments in 2009, clover alone or in combination with poultry litter led to higher pecan leaf $\mathrm{Zn}$ concentrations than the control and/or ammonium nitrate treatments (Table 2).

Although percent kernel was generally unaffected by treatments throughout much of the current study, nut weight was heavier for poultry litter than for clover + litter and ammonium nitrate during 2009, the year in which yields were the heaviest for each of these treatments and the control (Table 4). Yield was unaffected by treatment until the second year of study, in which the ammonium nitrate and control treatments had higher yields than the clover and clover + litter treatments. This may have been related to more severe alternate bearing in the ammonium nitrate treatment between the 2008 and 2009 growing seasons. During the final 2 years of study, the clover + poultry litter treatment had higher yields than the control; however, there were no differences between the remaining treatments. Over the course of the study, yields were more consistent from year to year in the clover, litter, and clover + litter treatments, as indicated by the low $I$ from 2008 to 2011 (Table 5). 
In summary, both poultry litter and clover appear to provide adequate $\mathrm{N}$ nutrition for pecan. This was reflected by pecan leaf concentration, yield, nut quality, and $I$. Poultry litter with and without clover can also provide many additional nutrients required by pecan trees, including $\mathrm{P}, \mathrm{K}, \mathrm{Fe}, \mathrm{Cu}$, and $\mathrm{Zn}$. Where clover is used in the orchard, additional $\mathrm{K}$ application may be necessary. Poultry litter and clover may also provide additional benefits for pecan nutrition, primarily through the addition of organic matter, which enhances the orchard soil environment (Wells, 2011b). Although pecan orchard systems may be less vulnerable than shallow-rooted annual cropping systems to the adverse effects of accumulation of nutrients such as N, P, and various heavy metals with poultry litter application, soil nutrient status should be closely monitored where poultry litter is routinely applied.

\section{Literature Cited}

Adams, W.E., M. Stelly, H.D. Morris, and C.B. Elkins. 1967. A comparison of Coastal and Common bermudagrasses in the Piedmont region. II. Effect of fertilization and crimson clover on nitrogen, phosphorous, and potassium contents of the forage. Agron. J. 59:281-284.

Allen, S.C., S. Jose, P.K.R. Nair, B.J. Brecke, P. Nkedi-Kizza, and C.L. Ramsey. 2004. Safety net role of tree roots: Evidence from a pecancotton alley cropping system in the southern United States. For. Ecol. Mgt. 192:395-407.
Conner, P.J. and R.E. Worley. 2000. Alternate bearing intensity of pecan cultivars. HortScience 35:1067-1069.

Dunkley, C.S., D.L. Cunningham, and G.H. Harris. 2011. The value of poultry litter in South Georgia. Univ. Georgia Coop. Ext. Bul. 1386.

Havlin, J.L., J.D. Beaton, S.L. Tisdale, and W.L. Nelson. 2005. Soil fertility and fertilizers. Pearson Prentice Hall, Upper Saddle River, NJ.

Huang, W. 2009. Factors contributing to the recent increase in U.S. fertilizer prices, 2002-2008. U.S. Dept. of Agr. Economic Research Service., AR-33. 8 Apr. 2011. <http://www.ers.usda. gov/Publications/AR33/AR33.pdf $>$.

Hudson, W., J. Brock, S. Culpepper, and L. Wells. 2011. Georgia pecan pest management guide. Univ. Georgia Coop. Ext. Bull. 841.

Kingery, W.L., C.W. Wood, D.P. Delaney, J.C. Williams, and G.L. Mullins. 1994. Impact of long term application of broiler litter on environmentally related soil properties. J. Environ. Qual. 23:139-147.

Mitchell, C.C. and S. Tu. 2005. Long term evaluation of poultry litter as a source of nitrogen for cotton and corn. Agron. J. 97:399-407.

Nunez-Moreno, H., J.L. Walworth, and A.P. Pond. 2009. Manure and soil zinc application to 'Wichita' pecan trees growing under alkaline conditions. HortScience 44:1741-1745.

Pearce, S.C. and S. Dobersek-Urbanc. 1967. The measurement of irregularity in growth and cropping. J. Hort. Sci. Biotechnol. 42:295305.

Rowe, E.C., K. Hairiah, K.E. Giller, M. van Noordwijk, and G. Cadisch. 1999. Testing the safety-net role of hedgerow tree roots by placement at different soil depths. Agrofor. Syst. 43:8193.

Smith, M.W., A. Shiferaw, and N.R. Rice. 1996. Legume cover crops as a nitrogen source for pecan. J. Plant Nutr. 19:1117-1130.

Sparks, D. 1989. Pecan nutrition: A review. Proc. Southeastern Pecan Growers Assn. 82:101-122.

Sparks, D. 2005. Adaptability of pecan as a species. HortScience 40:1175-1189.

Van Lam, H., N. Gammon, and W.B. Sherman. 1978. Copper requirement for pecan. Pecan South 5:90-91.

Wells, M.L. (ed.). 2007. Southeastern pecan growers handbook. Univ. Georgia Coop. Ext. Pub. 1327.

Wells, M.L. 2009a. Poultry litter budget for Georgia. Proc. Southeastern Pecan Growers Assn. 102:122-128.

Wells, M.L. 2009b. Pecan nutrient element status and orchard soil fertility in the southeastern United States coastal plain. HortTechnology 19:432-438.

Wells, M.L. 2011a. Nitrogen availability in pecan orchard soil: Implications for pecan fertilizer management. HortScience 46:1294-1297.

Wells, M.L. 2011b. Response of pecan orchard soil chemical and biological quality indicators to poultry litter application and clover cover crops. HortScience 46:306-310.

White, A.W., E.R. Beatty, and W.L. Tedders. 1981. Legumes as a source of nitrogen and effects of management practices on legumes in pecan orchards. Proc. Southeastern Pecan Growers Assn. 74:97-106.

Worley, R.E. 2002. Compendium of pecan production and research. Edwards Brothers Press, Ann Arbor, MI. 